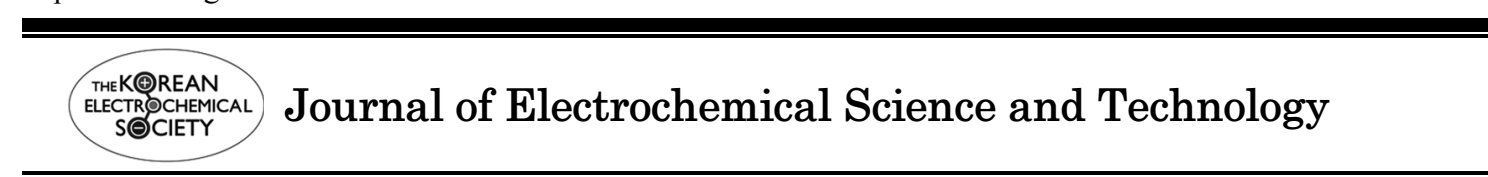

\title{
Electrochemical behaviors of Indium
}

\author{
Yonghwa Chung and Chi-Woo Lee ${ }^{\dagger}$ \\ Department of Advanced Materials Chemistry, Korea University, Jochiwon, Choongnam 339-700, Republic of Korea
}

\begin{abstract}
:
Many researchers focus on indium contained semiconductors and alloy compounds for their various applications. Electrochemists want to obtain indium contained compounds simply via one-step electrodeposition. First of all, electrochemistry of constituent elements must be understood in order to develop the best condition for the electrodeposition of indium contained compounds. We will review the electrochemistry of indium. Equilibria between indium metal and indium ions and the standard electrode potentials of the equilibria will be reviewed. The electrochemical reactions of indium species are affected by surrounding conditions. Thus dependences of electrochemical behaviors of indium metal and indium ions on various parameters will be reviewed.
\end{abstract}

Keywords: Indium, Standard electrode potential, Reduction, Oxidation, Electrodeposition

Received February 21, 2012 : Accepted March 14, 2012

\section{Introduction}

Indium is a chemical element with the symbol In and atomic number 49. It is in 13 group of the periodic table. Indium was discovered in 1863 by F. Reich and $\mathrm{T}$. Richte, it was named after a indigo blue line in its spectrum. Indium is a silvery-white metal with a brilliant metallic luster. This rare metal is softer than lead, malleable, ductile, and crystalline. ${ }^{1)}$

Indium is a useful metal due to its applications to electronic and optoelectronic devices, solar cells, alkaline batteries, transparent conducting materials etc. Indium is mainly used as alloy compounds that are binary (Al-In, Bi-In, Pb-In etc.), ternary (Al-Sb-In, CdSn-In etc.), quaternary (Cd-Ge-Sn-In etc.) and quinary (Cd-Ge-Sn-Zn-In etc.) alloys. ${ }^{1,2}$ Generally, the addition small quantity of indium has the effect of hardening, strengthening, and increasing the corrosion resistance of the metal. Some indium alloys such as $\operatorname{InSb},{ }^{3-6)} \operatorname{InP}^{7,8)}$ $\mathrm{InN},{ }^{9,10)} \mathrm{InGaAs}^{11)} \mathrm{InSe}^{12)}$ are studied as optoelectronic materials, magneto resistive materials and anodic mate-

Corresponding author. Tel.: +82-41-860-1333

E-mail address: cwlee@korea.ac.kr rials of lithium battery. Indium oxide is used as transparent conducting materials in the form of Sn-doped $\operatorname{In}_{2} \mathrm{O}_{3}$ (indium tin oxide, ITO). ${ }^{13,14)}$ Because ITO films are optically transparent and electrically conductive in thin layers, glass fabricated ITO thin films are used for photovoltaic applications like liquid crystal displays. Currently there are many researchers who try to develop solar cells using indium contained semiconductors, such as InN ${ }^{15,16)} \operatorname{InGaN},{ }^{17,18)} \mathrm{CuInS}(\mathrm{Se})_{2} / \mathrm{CuInGaS}(\mathrm{Se})_{2} \cdot{ }^{19-22)}$

Physical and chemical properties of indium have been well known through several references. ${ }^{1,23,24)}$ Piercy et al. ${ }^{25)}$ and Losev et al. ${ }^{26)}$ reviewed basic electrochemistry of indium. Electrochemistry of indium has been studied by many researchers since 1930. Most of researches focused on the reduction and oxidation for indium ions and indium metal. It is known that the cathodic reduction of $\mathrm{In}^{3+}$ and the anodic dissolution of indium metal occur in two charge-transfer steps and $\mathrm{In}^{+}$ is an intermediate species during the electron transfer processes of $\mathrm{In}^{3+} / \mathrm{In}^{0}$. In this paper, we will review the electron transfer processes of $\mathrm{In}^{3+} / \mathrm{In}^{0}$ in various circumstances and the nucleation and the growth of indium metal produced by cathodic reduction of $\mathrm{In}^{3+}$ on the surface of an electrode. 


\section{The Standard Electrode Potential of Indium}

The standard potential of the $\mathrm{In}^{3+} / \mathrm{In}^{0}$ was determined by measuring the electrode potential in aqueous chloride, ${ }^{27,28)}$ sulfate ${ }^{28,29,30)}$ and sulfate-perchlorate solutions $^{31)}$ and was approximately $-0.34 \mathrm{~V}$ vs. SHE.

Hamer et al. calculated theoretical electromotive forces for $\mathrm{In}^{2+} / \mathrm{In}^{0}$ and $\mathrm{In}^{3+} / \mathrm{In}^{0}$ in molten metal chloride electrolyte at various temperatures. ${ }^{32)}$

Hepler et al. ${ }^{33)}$ calculated the standard potentials of $\mathrm{In}^{+} / \mathrm{In}^{0}, \mathrm{In}^{2+} / \mathrm{In}^{+}$and $\mathrm{In}^{3+} / \mathrm{In}^{2+}$ from equilibrium constants of the equilibriums between $\operatorname{In}^{3+}(\mathrm{aq})$ and $\operatorname{In}^{0}(\mathrm{~s})$. The results were as follows

$$
\begin{array}{ll}
\mathrm{In}^{+}+e \rightarrow \operatorname{In} & E^{\mathrm{o}}=-0.14 \mathrm{~V} \\
\mathrm{In}^{2+}+e \rightarrow \mathrm{In}^{+} & E^{\mathrm{o}}=-0.40 \mathrm{~V} \\
\mathrm{In}^{3+}+e \rightarrow \mathrm{In}^{2+} & E^{\mathrm{o}}=-0.49 \mathrm{~V} \text { vs. SHE. }
\end{array}
$$

Visco ${ }^{34)}$ evaluated the potential of $\operatorname{In}^{+} / \operatorname{In}^{0}$ in the study of the homogeneous oxidation of $\mathrm{In}^{+}$. The standard potential of $\mathrm{In}^{+} / \mathrm{In}^{0}$ was $-0.126 \mathrm{~V}$ vs. SHE at $20^{\circ} \mathrm{C}$ in $0.70 \mathrm{M} \mathrm{HClO}_{4}$. G. Biedermann and T. Wallin ${ }^{35)}$ determined the standard potentials of $\mathrm{In}^{3+} / \mathrm{In}^{+}$and $\mathrm{In}^{3+} / \mathrm{In}^{0}$ at $25^{\circ} \mathrm{C}$ in $3 \mathrm{M} \mathrm{ClO}_{4}^{-}$. They could estimate $E_{3,1}^{\mathrm{o}}=-425.5 \pm$ $1 \mathrm{mV}$ and $E_{3,0}^{\mathrm{o}}=-343 \pm 1 \mathrm{mV}$, as the most probable values.

\section{Electrochemical Reactions of Indium Metal and Indium Ions}

\subsection{Indium metal in aqueous solution}

Indium metal dissolves in mineral acids and generates $\mathrm{In}^{3+}$ ion. The $\mathrm{In}^{3+}$ ion in an aqueous solution forms the hexaquo complex, $\operatorname{In}\left(\mathrm{H}_{2} \mathrm{O}\right)_{6}{ }^{3+}$, which is hydrolysed to $\operatorname{In}\left(\mathrm{H}_{2} \mathrm{O}\right)_{5}(\mathrm{OH})^{2+}$ and $\operatorname{In}\left(\mathrm{H}_{2} \mathrm{O}\right)_{4}(\mathrm{OH})_{2}{ }^{+}$ions before electron-transfer process. Biedermann et al. ${ }^{36)}$ claimed that when the concentration of indium was less than $0.001 \mathrm{M}$, the ions $\mathrm{In}(\mathrm{OH})^{2+}$ and $\operatorname{In}(\mathrm{OH})_{2}{ }^{+}$predominated among the hydrolysis products. On the other hand the binuclear species $\mathrm{In}_{2}(\mathrm{OH})_{2}{ }^{4+}$ and other polynuclear ions of the general composition $\operatorname{In}\left(\operatorname{In}(\mathrm{OH})_{2}\right)_{\mathrm{t}}{ }^{(3+\mathrm{t})^{+}}$became increasingly important as the solutions got more concentrated for $\mathrm{In}^{3+} ; \mathrm{t}$ was assumed to represent an integer growing without limit. Losev and Molodov ${ }^{37)}$ reported that for the cathodic reduction of the hydrated indium ion, the rate was first order with respect to hydroxyl concentration. In their another report, ${ }^{38)}$ they found parallel reduction processes: indium was formed either by direct discharge of $\mathrm{In}\left(\mathrm{H}_{2} \mathrm{O}\right)_{6}{ }^{3+}$ ion, or by discharge of partially hydrolysed indium ions, $\left[\mathrm{In}\left(\mathrm{H}_{2} \mathrm{O}\right)_{5} \mathrm{OH}\right]^{2+}$. The rate constant of the former process was about $10^{5}$ times less than that of the latter. Accordingly the slow cathodic reduction of $\mathrm{In}^{3+}$ is to be ascribed to the difficulty of removing a hydrogen ion from the bound hydration shell of the $\mathrm{In}^{3+}$ ion.

\subsection{Electrochemical reactions of indium metal and indium ions in aqueous solution}

The equilibriums between $\operatorname{In}^{3+}(\mathrm{aq})$ and $\operatorname{In}^{0}(\mathrm{~s})$ were investigated by Hepler et al. ${ }^{33)}$ They determined equilibrium constants for the reactions:

$$
\begin{aligned}
& 2 \operatorname{In}^{0}(\mathrm{~s})+\operatorname{In}^{3+}(\mathrm{aq}) \leftrightarrow 3 \operatorname{In}^{+} \\
& \operatorname{In}^{0}(\mathrm{~s})+2 \operatorname{In}^{3+}(\mathrm{aq}) \leftrightarrow 3 \operatorname{In}^{2+}
\end{aligned}
$$

In their study $\mathrm{In}^{2+}$ as well as $\mathrm{In}^{+}$in the equilibrium was presumed to be present. However except for one polarogram of the equilibrated solution shown by Marple, ${ }^{34)}$ any evidences other than titrimetry and potentiometry did not exist for intermediate indium oxidation state $\left(\mathrm{In}^{2+}\right)$.

Clark et al. ${ }^{39)}$ identified the +1 oxidation state of indium. They prepared indium monohalides by reaction of the metal with appropriate quantities of mercury (I) or mercury (II) halides. They demonstrated the unlikelyhood of the existence of $\mathrm{InCl}_{2}$ by a phase study of the system $\mathrm{InCl}_{-} \mathrm{InCl}_{3}$. Biedermann et al. ${ }^{35)}$ reported the equilibrium between $\mathrm{In}^{3+}, \mathrm{In}^{0}$ and $\mathrm{In}^{+}$in the ionic medium of $3 \mathrm{M} \mathrm{ClO}_{4}^{-}$at $25^{\circ} \mathrm{C}$ by bringing indium (III) perchlorate solutions into intimate contact with finely divided indium metal. After a steady state was attained in the solution, a number of equilibriums of reducing agents was formed. They could explain their data well by assuming that only the $\mathrm{In}^{+}$ion was formed and that for the equilibrium of eq. (4), $\mathrm{In}^{3+}+2 \operatorname{In} \leftrightarrow 3 \mathrm{In}^{+}, \log$ $\mathrm{K}=-8.4 \pm 0.1$. And they didn't find any evidence for presence of the species $\mathrm{In}^{2+}$.

The upper limit of the stability region of $\mathrm{In}^{3+}$ in aqueous solution is about $\mathrm{pH} 2.5$ and at $\mathrm{pH} 3-5$, the indium metal tends to be covered with a film of the $\operatorname{In}_{2} \mathrm{O}_{3}$ or $\mathrm{In}(\mathrm{OH})_{3}{ }^{40)}$

Hampson et al. ${ }^{41)}$ measured the potential of the $\mathrm{In}^{3+} /$ $\mathrm{In}^{0}\left(\mathrm{In}_{(\mathrm{s})}\left|\mathrm{InCl}_{3(\mathrm{aq})}, \mathrm{HCl}_{(\mathrm{aq})}\right| \mathrm{AgCl}_{(\mathrm{s})} \mid \mathrm{Ag}_{(\mathrm{s})}\right)$ at a series of $\mathrm{pH}$ value. In solutions of $\mathrm{pH}$ in the region $<\sim 2.7$, an indium electrode behaved in a satisfactory manner but at $\mathrm{pH}$ 's $>\sim 2.7$, the potential changes markedly for small changes of $\mathrm{pH}$. They explained that the electrode reaction, $\mathrm{In}^{3+}+3 \mathrm{e} \leftrightarrow \mathrm{In}^{0}$, was complicated by the pres- 


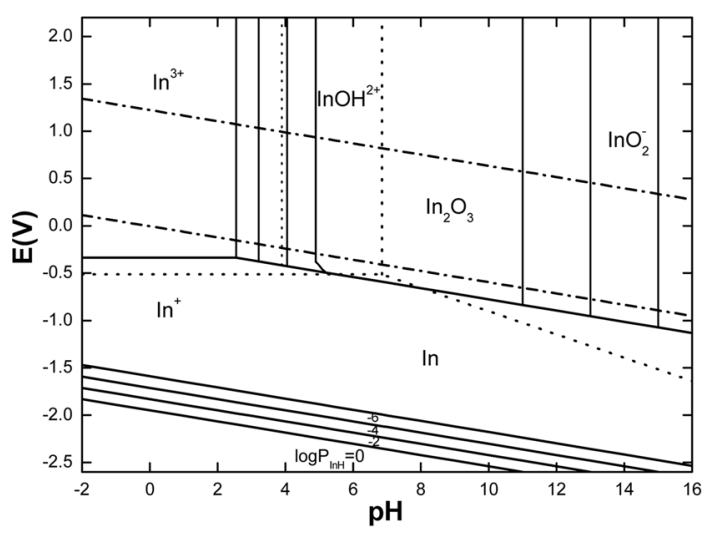

Fig. 1. Potential-pH equilibrium diagram for the system Indium-water, at $25^{\circ} \mathrm{C}$ [modified from Fig. 1 in p. 439 of reference 40].

ence of phase hydroxide (or oxide) at the electrode, according to an equation of the type:

$$
\operatorname{In}(\mathrm{OH})_{3}(\mathrm{~s})+3 \mathrm{e} \leftrightarrow \operatorname{In}+3 \mathrm{OH}^{-}
$$

Their results showed that the hydrolysis of $\mathrm{InCl}_{3}$ was important at certain $\mathrm{pH}$ values and that a satisfactory estimate of $E_{\mathrm{o}}$ and $\left(\partial E_{\mathrm{o}}{ }^{\prime} / \partial \mathrm{T}\right)_{\mathrm{p}}$ for the $\mathrm{In}^{3+} / \mathrm{In}^{0}$ couple could only be made if this hydrolysis did not interfere with the electrode reaction, $\operatorname{In}^{3+}+3 \mathrm{e} \leftrightarrow \operatorname{In}^{0}$.

It is generally accepted that the three-electron chargetransfer process for the electrochemical deposition of $\mathrm{In}^{3+}$ ions and the anodic dissolution of indium metal occurs in two consecutive charge-transfer steps and involves an $\mathrm{In}^{+}$ion as an intermediate. Many research groups showed that the three electron charge-transfer process was not 1-step reaction. Lovrecek et al. ${ }^{42)}$ studied the kinetics of the deposition and dissolution of indium (from indium amalgam) in indium sulfate solution at $\mathrm{pH} 2.5$ by observing variations of overpotential during individual constant current pulses. For the electrochemical deposition and dissolution of indium in the region of lower current densities $\left(<2.5 \times 10^{-3} \mathrm{~A} \mathrm{~cm}^{-2}\right)$ it was found that the mechanism consisted of three consecutive electron transfer steps:

$$
\mathrm{In}^{3+} \stackrel{+\mathrm{e}}{\longleftarrow} \mathrm{In}^{2+} \stackrel{+\mathrm{e}}{\longleftarrow} \mathrm{In}^{+} \stackrel{+\mathrm{e}}{\longleftarrow} \mathrm{In}^{0}
$$

At lower current density, the rate-determining step for both anodic and cathodic polarization was

$$
\mathrm{In}^{3+} \stackrel{+\mathrm{e}}{\stackrel{-\mathrm{e}}{\longrightarrow}} \mathrm{In}^{2+}
$$

This result was consistent with a mechanism pro- posed by other groups previously. ${ }^{43,44)}$ Visco $^{45)}$ focused on a search for an intermediate during the electrochemical oxidation of indium metal or its amalgam. In the electrochemical oxidation of either indium metal or its amalgam to the $\mathrm{In}^{3+}$ ion in a stirred acidic noncomplexing medium, $\mathrm{In}^{+}$ion was an important intermediate. The $\mathrm{In}^{+}$ion formed during oxidation of indium metal was detected polarographically in the bulk of the solution. But the role played by $\mathrm{In}^{+}$in the oxidation of the indium metal or its amalgam was not yet clear. He also proposed a mechanism of three steps and showed that the formation of $\mathrm{In}^{+}$was the first step and the last electron transfer step was rate-determining for the anodization of indium metal. In their further study, ${ }^{46)}$ they detected $\mathrm{In}^{+}$ species formed during the anodic dissolution of indium metal in $0.7 \mathrm{M} \mathrm{HClO}_{4}$ by means of the rotating diskring electrode technique. The $\mathrm{In}^{+}$ion obtained through a rapid one-electron reaction was sufficiently stable to be detected in theoretical amount at the ring. The ring current-potential curves showed that the slowness of the $\mathrm{In}^{+} / \mathrm{In}^{3+}$ reaction permitted the thermodynamically lessfavored state to be formed in quantity.

Markovac and Lovrecek ${ }^{47)}$ observed a change in the mechanism of the deposition and dissolution of indium at current density higher than $2.5 \times 10^{-3} \mathrm{~A} \mathrm{~cm}^{-2}$. To study the phenomenon, the cathodic and anodic polarization in solutions of indium sulfate with $\mathrm{pH} 2.5,1.56$ and 1.0 was investigated. On the basis of the shape of the the $\eta_{\mathrm{A}}-\log _{10} i$ curve and their earlier considerations it followed, ${ }^{42)}$ that going from lower current densities to higher ones, a change in the mechanism of the deposition of indium occurred. They explained that one mechanism was predominant at lower current densities and the other at higher current densities, while in the region between both processes were possible. They suggested the mechanism that consisted of two steps at higher current density:

$$
\mathrm{In}^{3+} \stackrel{+2 \mathrm{e}}{\longrightarrow} \mathrm{In}^{+} \stackrel{+\mathrm{e}}{\longrightarrow} \mathrm{In}^{0}
$$

Analysis of the experimental data obtained by cathodic polarization in indium sulfate solution at higher current density pointed to the reaction step, $\mathrm{In}^{3+}+2 \mathrm{e} \rightarrow \mathrm{In}^{+}$, as rate-determining. For anodic polarization they could conclude that a disproportionation reaction occurred with increasing current density, and that the first anodic reaction step $\operatorname{In}^{0}-\mathrm{e} \rightarrow \mathrm{In}^{+}$became rate determining.

Under a certain condition $\mathrm{In}^{+}$ion obtained during deposition and dissolution of indium can be reduced to 
$\mathrm{In}^{0}$ and/or oxidized to $\mathrm{In}^{3+}$. According to Kangro's report, ${ }^{30)}$ the reduction process of $\mathrm{In}^{3+}$ ion was masked by hydrogen evolution reaction in the region of low $\mathrm{pH}$. Visco $^{34)}$ investigated the kinetics of the homogeneous oxidation of $\mathrm{In}^{+}$ion by $\mathrm{H}^{+}$in perchlorate solution using a dropping mercury electrode. He reported that the chemical reaction for the disappearance of $\operatorname{In}^{+}$must be

$$
\mathrm{In}^{+}+2 \mathrm{H}^{+} \rightarrow \mathrm{In}^{3+}+\mathrm{H}_{2}
$$

He showed the rate law for the disappearance of $\mathrm{In}^{+}$ ion was found to be: rate $=k\left[\mathrm{In}^{+}\right]\left[\mathrm{H}^{+}\right]$. Losev et al. ${ }^{48)}$ also reported that the corrosion of indium metal was stepwise dissolving reaction and the corrosion of indium in acidic perchlorate solutions proceeded by the complex electrochemical-chemical (EC) mechanism containing the oxidation step of $\mathrm{In}^{+}$by the reduction of $\mathrm{H}^{+}$ions.

Markovac et al. ${ }^{49)}$ studied the dependence of the mechanism of electrochemical deposition and dissolution of indium on electrolytes. They carried out anodic and cathodic polarization in pure chloride electrolyte and in combined sulfate-chloride electrolyte. The analysis of experimental data obtained by polarization in indium chloride solutions indicated that in the wide range of current densities up to $1.0 \times 10^{-1} \mathrm{~A} \mathrm{~cm}^{-2}$, the cathodic and anodic processes occurred near the equilibrium potential. For the cathodic polarization in chloride solutions, at higher current densities the first step was the slowest one. The same was found in the case of electrochemical deposition of indium in sulfate solutions for lower current densities.

$$
\mathrm{In}^{3+} \underset{\text { slowest }}{\stackrel{+\mathrm{e}}{\longrightarrow}} \mathrm{In}^{2+} \stackrel{+\mathrm{e}}{\longrightarrow} \mathrm{In}^{+} \stackrel{+\mathrm{e}}{\longrightarrow} \mathrm{In}^{0}
$$

In the case of anodic polarization of indium in chloride solutions in the region of higher current densities, the first step was the slowest one.

$$
\mathrm{In}^{0} \underset{\text { slowest }}{\stackrel{-\mathrm{e}}{\longrightarrow}} \mathrm{In}^{+} \stackrel{-\mathrm{e}}{\longrightarrow} \mathrm{In}^{2+} \stackrel{-\mathrm{e}}{\longrightarrow} \mathrm{In}^{3+}
$$

They also suggested that the dispropotionation reactions probably took place during anodic polarization. They obtained the $\eta_{\mathrm{A}}-\log _{10} i$ curves for cathodic and anodic polarization of $\mathrm{In}^{3+}$ in the combined sulfate-chloride solutions (Fig. 2). When the concentration of chloride in combined sulfate-chloride electrolytes increased, a linear part of $\eta_{\mathrm{A}}-\log _{10} i$ curve shifted to higher current density region. They explained that this fact was in accordance with the conception of the activating effect of chlorides and inhibiting effect of sulfates. It was con-

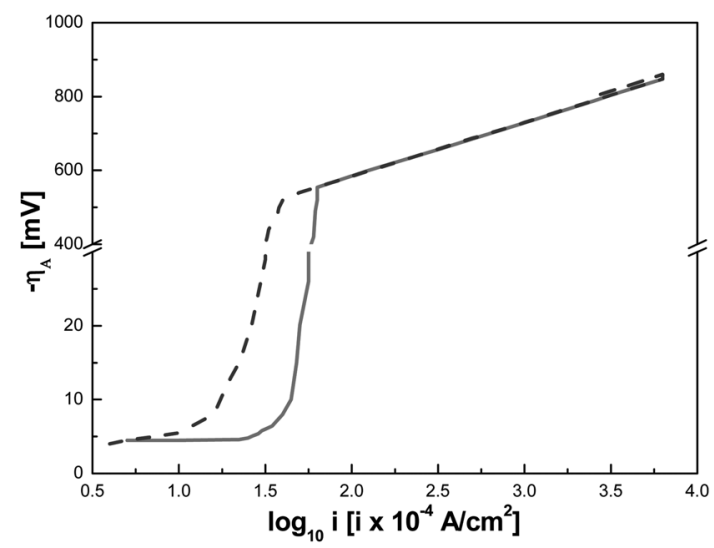

Fig. 2. $\eta_{\mathrm{A}}-\log _{10} i$ curves for cathodic polarization of $\operatorname{In}^{3+}$. Electrolyte, $0.116 \mathrm{~N} \mathrm{In}_{2}\left(\mathrm{SO}_{4}\right)_{3}+0.5 \mathrm{~N} \mathrm{~K}_{2} \mathrm{SO}_{4}+\mathrm{KCl}, \mathrm{pH}=2.5$; dashed, $0.05 \mathrm{~N} \mathrm{KCl}$; solid, $0.075 \mathrm{~N} \mathrm{KCl}$ [modified from Fig. 3 in reference 49].

cluded that in the range of current densities before the steep increased, deposition of indium occurred by analogous mechanism as in the pure chloride solution. In the range after the steep increased, deposition of indium occurred as in the pure sulfate medium. This rapid change in the mechanism of deposition of indium in combined sulfate-chloride electrolytes could be explained by conceptions about the mechanism of the activating effect of chloride on the deposition of metals, ${ }^{50,51)}$ and the desorption of chloride by increasing the negative potential. ${ }^{52)}$

For the study of deposition and dissolution of indium, one of important variables is the electrolyte used. The most studies of deposition and dissolution of indium were carried out in perchlorate, sulfate and halide. Halide is known to form a complex with an indium ion. The formation mechanism and stability constants of indium halogenide complexes were investigated. ${ }^{53-55)}$ In the presence of halide ions $\left(\mathrm{Cl}^{-}, \mathrm{Br}^{-}, \mathrm{I}^{-}\right), \mathrm{In}^{3+}$ exists in the form of complexes of $\operatorname{In} \mathrm{X}^{2+}, \operatorname{InX}_{2}^{+}, \operatorname{InX}_{3}$ and $\operatorname{In} \mathrm{X}_{4}^{-}$. Malyszko et al. ${ }^{56-61)}$ investigated the mechanism and kinetics of electroreduction of $\mathrm{In}^{3+}$ in bromide and chloride. First they studied the mechanism of the indium electrodeposition on gold from acidic $\mathrm{KBr}$ solutions by means of a rotating ring-disc electrode technique. ${ }^{56}$ During the $\mathrm{In}^{3+}$ reduction on the disc, the limiting ring current recorded as a function of the time of electrolysis. At the beginning of electrolysis the ring current did not appear and the disc surface was partially covered with a thin layer of indium metal which was called a primary layer. After the primary indium layer was formed, the 
ring current began to flow thus indicating that the $\mathrm{In}^{+}$ ions were produced at the disc surface. The results of their measurements showed that the overall electrode reaction, $\mathrm{In}^{3+}+3 \mathrm{e} \rightarrow \mathrm{In}^{0}$, consists of two successive charge transfer steps, i.e. $\mathrm{In}^{3+}+2 \mathrm{e} \rightarrow \mathrm{In}^{+}$and $\mathrm{In}^{+}+\mathrm{e} \rightarrow$ In, with soluble monovalent indium as an intermediate. Based on the ring current transients, it was established that the two-electron transfer step proceeded on the primary indium film and then the secondary indium active deposit was formed. The disproportionation of $\mathrm{In}^{+}$in the bulk of solution occurred in slightly

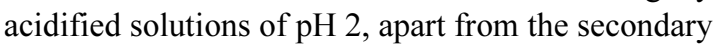
film formation on the electrode surface. Malyszko et al. determined the electrode kinetic parameter of cathodic reduction of $\mathrm{In}^{3+}$ to $\mathrm{I}^{+}$in acidic $4 \mathrm{M}$ bromide solution by means of the rotating disc electrode technique. ${ }^{57)}$ They evaluated the apparent standard rate constant, $k=3.5 \times 10^{-4} \mathrm{~cm} \mathrm{~s}^{-1}$ and cathodic apparent transfer coefficient, $\mathrm{n} \alpha_{\mathrm{c}}=0.86$ for the reaction, $\mathrm{In}^{3+}+2 \mathrm{e} \rightarrow \mathrm{I}^{+}$. Based on kinetic parameters they suggested that the two-electron transfer reaction would proceed by successive single-electron steps and the two-electron transfer reduction process was controlled by the first electron transfer, $\mathrm{In}^{3+}+\mathrm{e} \rightarrow \mathrm{I}^{2+}$, while the second step, $\mathrm{In}^{2+}+\mathrm{e} \rightarrow \mathrm{I}^{+}$, would be relatively fast. Malyszko et al. carried out the cathodic reduction of indium at a gold electrode in a wide range of $\mathrm{ZnBr}_{2}$ concentrations, from 1.0 to $9.4 \mathrm{M}^{58)}$ With increasing concentration of $\mathrm{ZnBr}_{2}$, the three-electron wave of $\mathrm{In}^{3+}$ reduction gradually split into two waves, which correspond to the $\mathrm{In}^{3+} / \mathrm{In}^{+}$and $\mathrm{In}^{+} / \mathrm{In}^{0}$ electrode reactions, respectively. Splitting into distinct two cathodic waves was because of the thermodynamic stabilization of $\mathrm{In}^{+}$in a high concentration of bromide. According to their opinion the changes in the stability of $\mathrm{In}^{+}$may be explained as being due to the superposition of two important factors: (i) complexation of $\mathrm{In}^{+}$and $\mathrm{In}^{3+}$ by Br- ions and (ii) dehydration of $\mathrm{In}^{3+}$ which results from the decrease of water activity with increasing $\mathrm{ZnBr}_{2}$ concentration. They concluded that complexation of $\mathrm{In}^{+}$and $\mathrm{In}^{3+}$ had influence on the diffusion coefficients of the $\mathrm{In}^{+}$and $\mathrm{In}^{3+}$, the formal potentials, kinetic parameters of the $\mathrm{In}^{3+} / \mathrm{In}^{+}$reaction and the equilibrium of the disproportionation of $\mathrm{In}^{+}$. Again they suggested that the electrode reduction of $\operatorname{In}^{3+}$ proceeded in two steps, with the transfer of the first electron to $\mathrm{In}^{3+}$, i.e. $\mathrm{In}^{3+}+\mathrm{e} \rightarrow \mathrm{I}^{2+}$, being the rate-determining step.

It has been known that $\mathrm{In}^{+}$is unstable in aqueous solutions with respect to the disproportionation reaction:

$$
3 \operatorname{In}^{+} \leftrightarrow \operatorname{In}^{3+}+2 \operatorname{In}^{0}
$$

The equilibrium of the disproportionation reaction is influenced strongly by the nature and concentration of background electrolyte. Malyszko et al. ${ }^{59)}$ studied the reproportionation of indium and indium ions $\left(\mathrm{In}^{3+}+\right.$ $\left.2 \mathrm{In} \leftrightarrow 3 \mathrm{In}^{+}\right)$in acidic $\mathrm{KBr}$ solutions by means of the coulometric and potentiometric method. Based on the experimental results, a scheme of the reproportionation reaction was proposed with regard to the participation of bromide ions. They investigated the dependence of the $\mathrm{In}^{+}$equilibrium concentration on the concentration of $\mathrm{In}^{3+}$ in $\mathrm{KBr}$ solutions of two different concentrations. The dependence of $\log C_{\operatorname{In}(I)}$ on $\log C_{\text {In(III) }}$ was linear with a slope of 0.48 , which was greater than that theoretically predicted value of 0.33 . This deviation from the expected value could be due to the acid-base reaction between $\mathrm{In}^{3+}$ and $\mathrm{In}^{+}$which resulted in formation of $\mathrm{In}^{+} \cdot \mathrm{In}^{3+}$ complexes,

$$
4 \operatorname{In}^{3+}+2 \operatorname{In}^{0} \leftrightarrow 3 \operatorname{In}^{+} \cdot \operatorname{In}^{3+}
$$

However, the slope of 0.48 in the plots of $\log C_{I n(I)}$ vs. $\log C_{\text {In(III) }}$ indicated that the contribution of the acid-base reaction between $\mathrm{In}^{3+}$ and $\mathrm{In}^{+}$was not very important. They also determined the equilibrium constants of the reproportionation reaction and observed that the equilibrium constant increased about two orders of magnitude as the bromide concentration increased from 1 to $4 \mathrm{M}$. They suggested that the shift of the equilibrium of the reproportionation reaction in favor of $\mathrm{In}^{+}$was due to the formation of strong complexes with bromide ions. On the basis of the plots of the formal potentials for the $\mathrm{In}^{+} / \mathrm{In}^{0}, \mathrm{In}^{3+} / \mathrm{In}^{0}$ and $\mathrm{In}^{3+} / \mathrm{In}^{+}$, at higher bromide concentrations (close to $4 \mathrm{M}$ ), the following scheme for the reproportionation reaction could be supposed with regard to the participation of bromide ions:

$$
\mathrm{InBr}_{2}^{+}+2 \mathrm{In}^{0}+7 \mathrm{Br}^{-} \leftrightarrow 3 \mathrm{InBr}_{3}^{2-}
$$

They explained that a high thermodynamic stability of $\mathrm{In}^{+}$ions resulted not only from complexations of $\mathrm{In}^{+}$ ions with bromides but also from dehydration of $\mathrm{In}^{3+}$ upon drastically decreasing the water activity. Malyszko et al. ${ }^{60)}$ investigated the redox equilibria in the $\mathrm{In}^{3+}-\mathrm{In}^{+}$In system in acidified aqueous $\mathrm{KBr}$ solutions using the rotating ring-disc electrode technique. The spontaneous dissolution of indium metal formed onto gold by electroreduction of $\mathrm{In}^{3+}$ yielded $\mathrm{In}^{+}$ions. Informations about the equilibrium and mechanism of the reproportionation reaction of $\mathrm{In}^{+}$were drawn from measurements of the limiting ring current and disc potential as a function of the electrode rotation rate. They proved that the 
reproportionation reaction of $\mathrm{In}^{+}$occurred as a coupling of two electrochemical steps: In $\leftrightarrow \mathrm{In}^{+}+\mathrm{e}$, and $\mathrm{In}^{3+}+$ $2 \mathrm{e} \leftrightarrow \mathrm{In}^{+}$. The cathodic half-reaction was the rate-determining step, whereas the anodic half-reaction was reversible. In the further study of Malyszko's group, ${ }^{61)}$ they studied the mechanism of the cathodic reduction of $\mathrm{In}^{3+}$ at gold electrode in highly concentrated aqueous $\mathrm{ZnCl}_{2}$ solutions (higher than $7 \mathrm{M}$ ). The obtained equilibrium constants of the reproportionation reaction indicated that $\mathrm{In}^{+}$ions were thermodynamically stable in highly concentrated $\mathrm{ZnCl}_{2}$ solution which was known as a strong dehydrating agent. They concluded that the considerable alteration of the equiribrium of the reproportionation reaction was caused by two significant factors: complexation of $\mathrm{In}^{+}$(soft acid) by $\mathrm{Cl}^{-}$anions, and dehydration of $\mathrm{In}^{3+}$ (hard acid).

\subsection{Electrochemical reactions of indium metal and indium ions in molten ionic liquid}

Laitinen and $\mathrm{Liu}^{62)}$ measured electrode potentials of a number of oxidation-reduction sytems in a $\mathrm{LiCl}-\mathrm{KCl}$ melt at $450^{\circ} \mathrm{C}$. In the case of the $\mathrm{In}^{3+} / \mathrm{In}^{0}$ system, the standard potential evaluated on the basis of a three electron process was $-0.800 \mathrm{~V} \pm 0.009 \mathrm{~V}$ vs. $\mathrm{Pt}^{2+} / \mathrm{Pt}^{0}$. Anders and Plambeck ${ }^{63)}$ studied electrochemistry of the Group IB and IIIA elements in fused $\mathrm{AlCl}_{3}-\mathrm{NaCl}-\mathrm{KCl}$ eutectic at $135^{\circ} \mathrm{C}$. Indium metal in contact with the melt reacted with $\mathrm{Al}^{3+}$ ions to give aluminum metal and $\mathrm{In}^{+}$ions,

$$
3 \mathrm{In}^{0}+\mathrm{Al}^{3+} \rightarrow 3 \mathrm{In}^{+}+\mathrm{Al}^{0}
$$

The standard potential of $\operatorname{In}^{+} / \operatorname{In}^{0}$ couple must be more negative than that of $\mathrm{Al}^{3+} / \mathrm{Al}^{0}$ couple. $\mathrm{In}^{+}$could be further oxidized within the melt range; a voltammetric scan indicated oxidation at $1.2 \pm 0.1 \mathrm{~V} \mathrm{vs.} \mathrm{Al}^{3+} / \mathrm{Al}^{0}$. Likewise, the addition of $\mathrm{InCl}_{3}$ and subsequent scanning resulted in a cathodic wave at $1.1 \pm 0.1 \mathrm{~V} \mathrm{vs} . \mathrm{Al}^{3+} /$ $\mathrm{Al}^{0}$. However, at higher $\mathrm{In}^{+}$concentrations, $\mathrm{In}^{+}$did not oxidize quantitatively. Shafir and Plambeck ${ }^{64)}$ measured electrode potentials of indium and gallium couples in dilute solutions of the ionic species in fused $\mathrm{LiCl}-\mathrm{KCl}$ eutectic at $450^{\circ} \mathrm{C}$. Standard molar electrode potentials of $\mathrm{In}^{+} / \mathrm{In}^{0}, \mathrm{In}^{3+} / \mathrm{In}^{+}$and $\mathrm{Ga}^{3+} / \mathrm{Ga}^{0}$ were observed. They indicated that gallium metal oxidized to $\mathrm{Ga}^{3+}$ and oxidized $\mathrm{Ga}^{3+}$ ion reduced to metal directly. Indium, however, was oxidized first to the monovalent state, whose stability in this medium has been confirmed by the Raman study, ${ }^{65)}$ and was not further oxidized in the presence of metallic indium. Therefore they concluded that the indium potential measured by Laitinen ${ }^{62)}$ corresponded to the $\mathrm{In}^{3+} / \mathrm{In}^{+}$couple rather than the potential of $\mathrm{In}^{3+} /$ $\mathrm{In}^{0}$. Guibert et al. ${ }^{66)}$ investigated the electrochemical reduction of $\mathrm{Pb}^{2+}, \mathrm{Ag}^{+}, \mathrm{Ni}^{2+}, \mathrm{In}^{3+}$ and $\mathrm{Rh}^{3+}$, and the oxidation of $\mathrm{O}^{2-}, \mathrm{I}^{-}, \mathrm{S}^{2-}$ in a $\mathrm{PbCl}_{2}+\mathrm{KCl}$ melt with $23 \%$ $\mathrm{mol} \mathrm{KCl}$ at $440^{\circ} \mathrm{C}$. In their research, the current-potential curve of the reduction of $\mathrm{InCl}_{3}$ showed only one reduction wave, close to the cathodic limit. The slope of the plot $\log \left[\left(i_{d}-i\right) / i\right]$ vs. potential was $0.069 \mathrm{~V}(\mathrm{RT} /$ $2 \mathrm{~F}=0.070 \mathrm{~V}$ at $440^{\circ} \mathrm{C}$ ), indicating that the reaction involved a two-electron transfer $\left(\mathrm{In}^{3+}+2 \mathrm{e} \rightarrow \mathrm{In}^{+}\right)$. They reported that the formation of indium metal was not observed and the reduction of $\mathrm{In}^{+}$did not occur in their medium where $\mathrm{Pb}^{2+}$ was more easily reduced. Barbier et al. ${ }^{67)}$ studied the electrochemical behavior of indium in the fused equimolar $\mathrm{NaCl}-\mathrm{KCl}$ mixture and measured the standard equilibrium potential of $\mathrm{In}^{+} / \mathrm{In}$. Voltammetric results of $\mathrm{InCl}_{3}$ at $700^{\circ} \mathrm{C}$ showed that the electrochemical reduction of $\mathrm{In}^{3+}$ to indium metal followed two well-separated electrochemical steps: $\mathrm{In}^{3+}+2 \mathrm{e} \rightarrow \mathrm{In}^{+}$and $\mathrm{In}^{+}+\mathrm{e} \rightarrow \mathrm{In}^{0}$. They postulated that the electrochemical oxidation of indium metal to $\mathrm{In}^{3+}$ ions was coupled with slow chemical reaction [eq. (4)], $\mathrm{In}^{3+}+2 \mathrm{In}^{0} \rightarrow 3 \mathrm{In}^{+}$. Castrillejo et al. ${ }^{68)}$ studied the electrochemical behavior of indium ions on a tungsten electrode in the $\mathrm{ZnCl}_{2}-2 \mathrm{NaCl}$ melt at $450^{\circ} \mathrm{C}$. They measured the standard potential of the $\mathrm{In}^{3+} / \mathrm{In}^{+}$couple and observed that the $\mathrm{In}^{3+} / \mathrm{In}^{+}$exchange was quasi-reversible. They concluded that the $\mathrm{In}^{+} / \mathrm{In}^{0}$ couple must be more negative in potential than in $\mathrm{Zn}^{2+} / \mathrm{Zn}^{0}$ couple therefore indium metal in contact with the melt reacted quantitatively to give zinc metal and $\mathrm{In}^{+}$ions according with the reaction:

$$
\mathrm{ZnCl}_{2} \text { (dis) }+2 \operatorname{In} \text { (liq) } \leftrightarrow 2 \mathrm{InCl} \text { (dis) }+\mathrm{Zn} \text { (liq) }
$$

Mohamedi et al. ${ }^{69)}$ studied the reduction processes on glassy carbon electrode in molten $\mathrm{LiCl}-\mathrm{KCl}$ eutectic containing $\mathrm{InCl}_{3}$. The cathodic discharge of indium ions to form metallic indium was shown to take place by a consecutive two-step electrochemical reaction. They compared the experimental cyclic voltammograms to the simulated cyclic voltammograms for two-step metal deposition on an inert electrode in order to establish definitely the reaction pathway. They concluded that the first step, identified by the $\mathrm{In}^{3+} / \mathrm{In}^{+}$exchange, was reversible, whereas the secondary step which was characterized by the $\mathrm{In}^{+} / \mathrm{In}^{0}$ was quasi-reversible. Carpenter and Verbrugge ${ }^{70)}$ reported the electrodeposition of InSb onto platinum and glassy carbon from low temperature basic organic chloroindate molten salt. The melt, which 
consisted of $\mathrm{InCl}_{3}$ and 1-methyl-3-ethylimidazolium chloride with molar ratio of $45 / 55$ allowed the codeposition to be accomplished at $45^{\circ} \mathrm{C}$. They found that indium deposition could be achieved from the melt, although exact mechanism was unclear. Voltammetric results suggested that the redox reactions of $\operatorname{In}^{+} / \mathrm{In}^{0}$ and $\mathrm{In}^{3+} / \mathrm{In}^{0}$, as well as the redox conversion between $\mathrm{In}^{+}$ and $\operatorname{In}^{3+}$, all contributed significantly to the electrochemistry of this system. By controlling the electrode potential or electrolyte composition, it was possible to achieve a large range of indium to antimony composition ratios in the deposit. Lim and Sun et al. ${ }^{71)}$ studied the electrochemistry of indium with voltammetry and chronoamperometry on glassy carbon, tungsten and nickel electrodes in basic and acidic aluminum chloride1,2-dimethyl-3-propylimidazolium chloride $\left(\mathrm{AlCl}_{3}\right.$ DMPIC) molten salt at $27^{\circ} \mathrm{C}$. The addition of InCl to basic $\mathrm{AlCl}_{3}$-DMPIC resulted in a colorless solution with a metal-like precipitate. The results from voltammetric data and X-ray powder diffraction analysis suggested the possibility that might undergo a disproportionation reaction when $\mathrm{InCl}$ dissolved in basic $\mathrm{AlCl}_{3}$-DMPIC

$$
3 \mathrm{InCl}+2 \mathrm{Cl}^{-} \rightarrow 2 \mathrm{In}+\left[\mathrm{InCl}_{5}\right]^{2-}
$$

As shown above, in the basic melt $\operatorname{In}^{3+}$ was complexed as $\left[\mathrm{InCl}_{5}\right]^{2-}$, which could be reduced to indium metal on the electrode surface through a three-electron reduction process. Their preliminary results of the electrochemistry of indium in the acidic $\mathrm{AlCl}_{3}$-DMPIC melt showed that indium metal reacted with the acidic $\mathrm{AlCl}_{3}$ DMPIC melt to produce a colorless solution of $\mathrm{In}^{+}$and $\mathrm{InCl}_{3}$ in the acidic melt was found to be insoluble. Bouteillon et al. ${ }^{72)}$ also suggested the disproportionation of $\mathrm{InCl}$ in the fused $\mathrm{LiCl}-\mathrm{KCl}$ eutectic. Sun et al. again reported the electrochemistry of indium at glassy carbon, tungsten and nickel electrodes in a basic 1-ethyl-3methylimidazolium chloride/tetrafluoroborate (EMIC$\mathrm{BF}_{4}$ ) ionic liquid at $30^{\circ} \mathrm{C}^{73)} \mathrm{InCl}_{3}$ dissolved in basic EMIC- $\mathrm{BF}_{4}$ ionic liquid by taking up two chloride ions to form the $\left[\mathrm{InCl}_{5}\right]^{2-}$ complex anion. In this ionic liquid, $\left[\mathrm{InCl}_{5}\right]^{2-}$ could be reduced to indium metal. Effective anodic dissolution of indium metal required an excess amount of chloride ions.

\section{Electrodeposition Process of Indium}

\subsection{Electrodeposition of indium metal}

Electrochemical deposition of metals and alloys onto metallic substrates plays an important role in many modern technologies. Indium does not occur in the native state. Indium is most frequently associated with zinc, and is recovered commercially from zinc residues and smelter slags. For the recovery and refining of indium, electrochemical methods were applied.,74 Indium might be electroplated successfully onto nearly all metals and alloys. ${ }^{75)}$ The electrodeposition of indium is carried out in electrolyte solutions such as sulfate, cyanide, sulphamate, tartrate, formate. The most favoured electrolyte for the electrodeposition of indium is a sulfate solution. A few research groups reported the systematic study of electrochemical nucleation and growth during the electrodeposition of indium. Valderrama et al. ${ }^{76)}$ studied the electrodeposition and the oxidation process of indium on $\mathrm{Mo} / \mathrm{Cu}$ substrates from a bath containing $0.008 \mathrm{M} \mathrm{InCl}_{3}, 0.7 \mathrm{M} \mathrm{LiCl}$ at $\mathrm{pH} 3$. They evaluated the total efficiency of process, the number of monolayers, the film thickness and the diffusion coefficient using chronoamperometric technique. To determine three dimensional (3D) nucleation and growth type, the potentiostatic current transients for the deposition and oxidation of indium on $\mathrm{Mo} / \mathrm{Cu}$ were analyzed. The transients could be described by a mathematical model representing a three dimensional (3D) growth. In accordance with voltamperometric study and the evaluation of diffusion coefficient, $\mathrm{D}$, the indium deposit was controlled by a diffusion process. Thus the current transients could be described through a three dimensional growth for an instantaneous and a progressive nucleation as follow:

$$
\mathrm{j}=\frac{\mathrm{zFD}^{1 / 2} \mathrm{c}}{\pi^{1 / 2} \mathrm{t}^{1 / 2}}\left[1-\exp \left(-\mathrm{N}_{0} \pi \mathrm{KDt}\right)\right]
$$

for an instantaneous nucleation, and

$$
\mathrm{j}=\frac{\mathrm{zFD}^{1 / 2} \mathrm{c}}{\pi^{1 / 2} \mathrm{t}^{1 / 2}}\left[1-\exp \left(-\frac{2 \mathrm{AN}_{0} \pi \mathrm{KDt}^{2}}{3}\right)\right]
$$

for a progressive nucleation.

$\mathrm{N}_{0}$ is the number density of nucleation active sites $\left(\mathrm{cm}^{-2}\right)$. A is the steady-state nucleation rate per active site $\left(\mathrm{s}^{-1}\right)$. The other terms are defined in Cotrell's equation, except $\mathrm{K}$ which is the non-dimensional growth rate constant of a nucleus, defined as

$$
\mathrm{K}=\left(\frac{8 \pi \mathrm{Mc}}{\rho}\right)
$$

To determine whether the nucleation is instantaneous or 


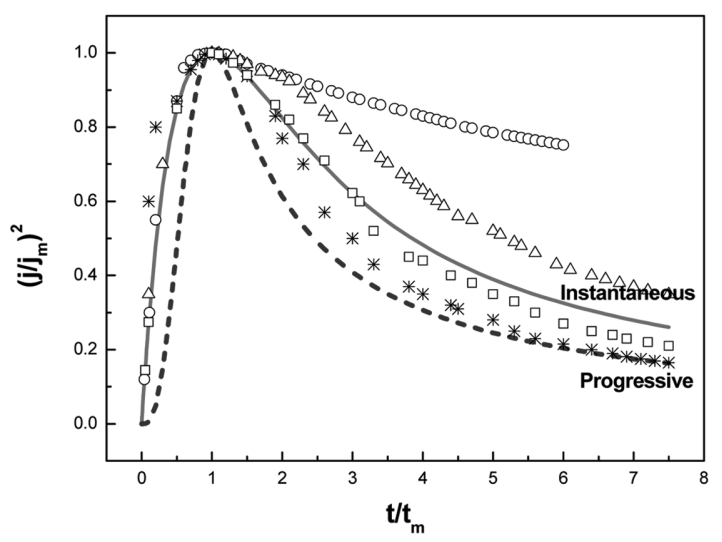

Fig. 3. A comparison of the theoretical non-dimensional plots $\left(\mathrm{j} / \mathrm{j}_{\mathrm{m}}\right)^{2}$ vs. $\left(\mathrm{t} / \mathrm{t}_{\mathrm{m}}\right)$ for instantaneous equation (Eq. 21) (solid line) and progressive equation (Eq. 22) (dashed line) nucleation with experimental data of the potentiostatic transients. The imposed potentials were: $(\bigcirc)-0.70 \mathrm{~V},(\Delta)$ $0.75 \mathrm{~V},(\square)-0.80 \mathrm{~V}$ and $(*)-0.85 \mathrm{~V}$ [modified from Fig. 4 in reference 76$]$.

progressive, the experimental and theoretical transients are normalized by their corresponding maximum value of current $\left(\mathrm{j}_{\mathrm{m}}\right)$ and time $\left(\mathrm{t}_{\mathrm{m}}\right)$. The non-dimensional expressions of the 3D nucleation and growth equations were obtained. For the instantaneous case is

$$
\left(\frac{\mathrm{j}}{\mathrm{j}_{\mathrm{m}}}\right)^{2}=\frac{1.9542}{\mathrm{t} / \mathrm{t}_{\mathrm{m}}}\left\{1-\exp \left[-1.2564\left(\frac{\mathrm{t}}{\mathrm{t}_{\mathrm{m}}}\right)^{2}\right]\right\}^{2}
$$

And for the progressive case is

$$
\left(\frac{j}{j_{m}}\right)^{2}=\frac{1.2254}{t / t_{m}}\left\{1-\exp \left[-2.3367\left(\frac{t}{t_{m}}\right)^{2}\right]\right\}^{2}
$$

By comparing the experimentally obtained data from the deposition of indium on $\mathrm{Mo} / \mathrm{Cu}$ with the theoretical curves, before reaching the maximum points, all of the experimental data followed the tendency of instantaneous nucleation. After for longer periods, during the current fall, the experimental curves were separated and when the imposed potential was more negative, the transient fell between the limits of instantaneous and progressive nucleations. Thus it appeared that the indium deposition was carried out under a 3D growth with instantaneous nucleation. Liu et al. ${ }^{77)}$ prepared $\mathrm{Cu}(\mathrm{In}, \mathrm{Ga}) \mathrm{Se}_{2}$ thin films on Mo/glass electrodes from aqueous solution containing sodium sulfamate electrolyte by pulse electrodeposition. The cyclic voltammetric studies showed the potential range $(-0.6 \mathrm{~V}$ vs. SCE) for
$\mathrm{Cu}, \mathrm{In}, \mathrm{Ga}$ and Se co-electrodeposition and the chronoamperometric investigation revealed that the co-deposition of the species occurred under 3D growth with instantaneous nucleation. Sun et al. investigated the electrodeposition of indium species at glassy carbon, tungsten and nickel electrodes in a basic $\mathrm{AlCl}_{3}$-DMPIC molten salt ${ }^{71)}$ and in a basic EMIC-BF 4 ionic liquid. ${ }^{73)}$ The electroreduction of $\left[\mathrm{InCl}_{5}\right]^{2-}$ to indium metal was preceded by overpotential driven nucleations. In a basic $\mathrm{AlCl}_{3}$-DMPIC molten salt, the deposition of indium on nickel electrodes was found to involve progressive three-dimensional nucleation on a large number of active sites with diffusion-controlled growth of the nuclei, whereas the deposition of indium on glassy carbon and tungsten electrodes was found to involve progressive three-dimensional nucleation on a finite number of active sites with diffusion-controlled growth of the nuclei. Indium metal appeared to be stable in a basic $\mathrm{AlCl}_{3}$-DMPIC molten salt. In a basic EMIC-BF ionic liquid, the electrodeposition of indium on glassy carbon and tungsten electrodes proceded via instantaneous three-dimensional nucleation with diffusion-controlled growth of the nuclei, while on nickel electrodes, the electrodeposition proceeded via progressive threedimensional nucleation with diffusion-controlled growth of the nuclei. Raising the deposition temperature decreases the average radius of the individual nuclei. Huang et al. ${ }^{78)}$ reported the electrodeposition of indium on copper in an acidic sulfate solution. They focused on the growth of an indium thin film, the film morphology and thickness uniformity on the nanometer scale. The electrodepositon of indium on copper went through two-step film growth behavior: the formation of continuous smooth layer was followed by the formation of the 3D island. Fast interdiffusion was observed between the electroplated copper and indium and $\mathrm{CuIn}_{2}$ alloy phase was formed during the indium deposition at room temperature. They suggested that while the alloy formation promoted the conformal deposition of a few indium monolayers, the fast interdiffusion between $\mathrm{Cu}$ and $\mathrm{In}$ further extended this alloy formation to a thicker layer and lowered the indium content at the surface and delayed the typical 3D island formation growth phenomenon.

\subsection{Electrodeposition of indium oxide}

Indium metal oxidizes to produce a film of $\operatorname{In}_{2} \mathrm{O}_{3}$ or $\mathrm{In}(\mathrm{OH})_{3}$ in an alkaline solution. Omanovic and Metikos-Hokovic ${ }^{79)}$ studied the mechanism and kinetics of 
nucleation and growth of indium oxide film on a bare metallic indium electrode in a borate solution of $\mathrm{pH}$ 10.0 using cyclic voltammetry and chronoamperometry techniques. The cyclic voltammograms of indium electrode showed very well defined single anodic and cathodic current peaks, the potential of which depends on the scan rate employed. These anodic and cathodic peaks were related to the reversible formation and reduction of an Indium oxide layer, respectively, according to the following:

$$
2 \mathrm{In}^{0}+6 \mathrm{OH}^{-} \leftrightarrow \mathrm{In}_{2} \mathrm{O}_{3}+3 \mathrm{H}_{2} \mathrm{O}+6 \mathrm{e}
$$

The experimental results showed that the oxide formation and reduction process was highly reversible and the initial stage of nucleation of the oxide film included a three dimensional progressive nucleation process, combined with a diffusion-controlled growth of the stable indium oxide crystals. The thermodynamic data obtained from this study indicated a strong tendency of indium to form an indium oxide film on its surface in an aqueous solution, which has been concluded on the basis of a very low nucleation overpotential and low Gibbs free energy of nuclei formation. The rate determining step in the nucleation and growth process was the surface diffusion of electroactiv species.

\section{Electrochemistry of Indium During the Electrodeposition of Semiconducting Mate- rials and Alloy Compounds Containing Indium}

The chalcopyrite materials such as $\mathrm{CuInSe}_{2}$ (CIS) and $\mathrm{Cu}$ (In, Ga) $\mathrm{Se}_{2}$ (CIGS) have been of interest for the photovoltaic conversion of solar energy. The alloy compounds containing indium such as, InSe and InSb studied for the uses of anodic material of lithium battery or magnetoresistive materials etc. There have been many attempts to prepare semiconductor thin film or indium contained alloys by one-step electrodeposition method. Here, electrochemical behaviors of indium during the electrodeposition of compounds containing indium will be reviewed.

Pottier and Maurin ${ }^{80)}$ prepared smooth and crystallized layers of the ternary semiconducting definite compound $\mathrm{CuInSe} \mathrm{S}_{2}$ on titanium substrates by the electrodeposition technique from aqueous medium containing citrate ions as complexing agent. They carried out this work to define the electrochemical conditions leading to the formation of $\mathrm{CuInSe}_{2}$ and found that the stoichiometry of $\mathrm{CuInSe}_{2}$ thin films depends upon the solution composition, applied potential and $\mathrm{pH}$ of the electrolyte. The best deposits were obtained at $\mathrm{E}=-0.97 \mathrm{~V}$ vs. SSE $\left(\mathrm{Hg} / \mathrm{Hg}_{2} \mathrm{SO}_{4}, \mathrm{~K}_{2} \mathrm{SO}_{4}\right.$ (sat.)), in a solution adjusted to $\mathrm{pH}$ 3.3. Mishra and Rajeshwar ${ }^{81)}$ studied the mechanism of formation of $\mathrm{CuInSe}_{2}$ thin films on a glassy carbon surface during voltammetric scanning. The data on the binary systems showed the facile formation of a $\mathrm{Cu}_{2-\mathrm{x}} \mathrm{Se}$ solid phase in the $\mathrm{Cu}+\mathrm{Se}$ system and the large nucleation overpotential associated with $\mathrm{In}^{3+}$ reduction and the kinetically sluggish interaction between In and Se in the In + Se system. A mechanistic system was proposed for the ternary system involving the concurrent formation of the $\mathrm{Cu}_{2-x} \mathrm{Se}$ phase, its subsequent reduction coupled with the reduction of $\mathrm{H}_{2} \mathrm{SeO}_{3}$ to $\mathrm{H}_{2} \mathrm{Se}$, and finally the underpotential assimilation of $\mathrm{In}^{3+}$ into the solid phase leading to $\mathrm{CuInSe}_{2}$. The cathodic reduction of the initial $\mathrm{Cu}_{2-\mathrm{x}} \mathrm{Se}$ was a pre-requisite for the formation of $\mathrm{CuInSe}_{2}$. They proposed that the thermodynamic driving force for the underpotential assimilation of $\mathrm{In}^{3+}$ leading to the formation of $\mathrm{CuInSe}_{2}$ was apparent from following reactions:

$$
\begin{aligned}
& \mathrm{In}^{3+}+\mathrm{CuSe}+\mathrm{H}_{2} \mathrm{Se}+\mathrm{e}^{-} \rightarrow \mathrm{CuInSe}_{2}+2 \mathrm{H}^{+} \\
& 3 \mathrm{In}^{3+}+\mathrm{Cu}_{3} \mathrm{Se}_{2}+4 \mathrm{H}_{2} \mathrm{Se}+\mathrm{e}^{-} \rightarrow 3 \mathrm{CuInSe}_{2}+8 \mathrm{H}^{+} \\
& \mathrm{In}^{3+}+\mathrm{CuSe}+\mathrm{Se}+3 \mathrm{e}^{-} \rightarrow \mathrm{CuInSe} \\
&
\end{aligned}
$$

An important feature of their model was that the cathodic reduction of the initial $\mathrm{Cu}_{2-\mathrm{x}} \mathrm{Se}$ was a pre-requisite for the formation of CuInSe $\mathrm{C}_{2}$. Thouin et al. ${ }^{82)}$ studied the electrodeposition of copper indium diselenide $\left(\mathrm{CuInSe}_{2}\right)$ in the presence of an excess of $\mathrm{In}^{3+}$ ions by voltammetric methods, X-ray diffraction analysis and chemical analysis of the deposits. Results showed that the presence of $\mathrm{In}^{3+}$ in the solution favored the reduction of $\mathrm{Se}^{4+}$ to $\mathrm{Se}^{2-}$ via the formation of CuInSe 2 . In the presence of an excess of $\mathrm{In}^{3+}$ in the deposition solution, the composition of the deposited thin film was limited by the ratio of the $\mathrm{Se}^{4+}$ and $\mathrm{Cu}^{2+}$ fluxes. The key factor was $\alpha=J_{S e} / J_{C u}$, the flux ratio of the species arriving at the electrode. At lower values of this flux ratio, two codeposition processes were observed, leading to the formation of either $\mathrm{CuInSe} \mathrm{C}_{2}+\mathrm{Cu}_{2} \mathrm{Se}$ mixture or $\mathrm{CuInSe}_{2}+\mathrm{Cu}$ mixtures. When the $\mathrm{Se}^{4+}$ flux was in excess, the two processes merged and only $\mathrm{CuInSe}_{2}+$ $\mathrm{In}_{2} \mathrm{Se}_{3}$ mixtures were obtained. The excess of $\mathrm{In}^{3+}$ not involved in $\mathrm{CuInSe}_{2}+\mathrm{In}_{2} \mathrm{Se}_{3}$ formation, was not reduced into the metallic state at $-1 \mathrm{~V}$ vs. MSE. In another study, ${ }^{83)}$ they studied the codeposition process 
of the $\mathrm{Cu}$-In-Se system in a lower concentration of $\mathrm{In}^{3+}$ ions where the electrodeposition process is limited by the diffusion of the three species. The composition of the film was fixed by both flux ratios $\alpha\left(J_{S e} / J_{C u}\right)$ and $\beta\left(J_{I n} / J_{C u}\right)$. In case of an excess of selenium flux, however, its total reduction at the -2 state $\left(\mathrm{Se}^{2-}\right)$ did not occur. The films showed then the presence of elemental Se. Oliveira et al. ${ }^{84)}$ studied the electrodeposition of $\mathrm{CuInSe}_{2}$ (CIS) on Mo substrate in acidic electrolyte using cyclic voltammetry. They carried out electrodeposition of CuInSe $\mathrm{C}_{2}$ on a Mo surface and a Mo-modified surface which represented a Mo substrate covered with $\mathrm{CuInSe} \mathrm{S}_{2}$ and probably CuSe and Se nucleation sites. They observed that the electrode reactions occurring on a Mo surface and on a Mo-modified surface were not the same. The presence of nucleation sites on Mo surface was responsible for the non-reduction of $\mathrm{Cu}_{\mathrm{x}} \mathrm{Se}$ on the electrode. The reduction of $\mathrm{In}^{3+}$ was not detected on a Mo electrode, but was recorded on a Mo-modified electrode at $-0.500 \mathrm{~V}$ potential. The presence of CIS nucleation sites appeared to induced the underpotential deposition of indium. They concluded that the assimilation of indium into the solid phase could proceed through two different routes: the $\mathrm{In}^{3+}$ ions may chemically react with a product of the $\mathrm{Cu}_{\mathrm{x}} \mathrm{Se}$ reduction reaction (e.g. $\mathrm{H}_{2} \mathrm{Se}$ ) and/or the $\mathrm{In}^{3+}$ ions may be electrochemically reduced to indium metal by a surfaceinduced deposition mechanism. In both cases the reactions leaded to the underpotential deposition of indium. Ishizaki et al. ${ }^{85)}$ reported the electrodeposition of copper indium ditelluride $\left(\mathrm{CuInTe}_{2}\right)$ from an acidic solution. $\mathrm{CuInTe}_{2}$ films might be formed by electrodepositing $\mathrm{Cu}_{2} \mathrm{Te}$ with incorporation (induced-codeposition) and/or underpotential deposition of indium. They recorded the cathodic polarization curve from an acidic bath of mixture of $\mathrm{CuCl}_{2}, \mathrm{InCl}_{3}$ and $\mathrm{TeO}_{2}$. According to the cathodic polarization curve and the Pourbaix-type diagram, ${ }^{86)}$ the charge transfer reaction at $0 \mathrm{mV}$ vs. $\mathrm{Ag} / \mathrm{AgCl}$ was related to the reduction of the copper telluride formed as follow:

$$
2 \mathrm{Cu}^{2+}+\mathrm{HTeO}_{2}^{+}+3 \mathrm{H}^{+}+8 \mathrm{e}^{-} \rightarrow \mathrm{Cu}_{2} \mathrm{Te}+2 \mathrm{H}_{2} \mathrm{O}
$$

The second charge transfer reaction at $-400 \mathrm{mV}$ showed the reduction of $\mathrm{Cu}_{2} \mathrm{Te}$ with $\mathrm{In}^{3+}$ in the solution. The Pourbaix-type diagram showed that $\mathrm{Cu}_{2} \mathrm{Te}$ reduction leaded to $\mathrm{H}_{2}$ Te generation. The $\mathrm{H}_{2} \mathrm{Te}$ could react with $\mathrm{In}^{3+}$ :

$$
2 \mathrm{In}^{3+}+3 \mathrm{H}_{2} \mathrm{Te} \rightarrow \mathrm{In}_{2} \mathrm{Te}_{3}+6 \mathrm{H}^{+}
$$

$$
\mathrm{Cu}_{2} \mathrm{Te}+3 \mathrm{H}_{2} \mathrm{Te}+2 \mathrm{In}^{3+} \rightarrow 2 \mathrm{CuInTe}_{2}+6 \mathrm{H}^{+}
$$

However, XRD data showed the films obtained by potentiostatic deposition at $-400 \mathrm{mV}$ were not crystalline. They could not determine the films were $\mathrm{CuInTe}_{2}$ compound phase. They obtained the $\mathrm{CuInTe}_{2}$ films from an acidic bath of $\mathrm{pH} 1$, deposition potential ranging from -660 to $-500 \mathrm{mV}$, and the bath temperature at $363 \mathrm{~K}$. Whang et al. studied the single-step electrodeposition of $\mathrm{CuInSe}_{2}$ on ITO glass from aqueous acidic solution containing $\mathrm{CuCl}_{2}, \mathrm{InCl}_{3}$ and $\mathrm{SeO}_{2}$ with complexing agents that were triethanolamine (TEA) ${ }^{87)}$ and sodium citrate. ${ }^{88)}$ The $\mathrm{CV}$ diagrams of individual metal ions with TEA (Fig. 4 (b)) showed that TEA formed complexes with copper ions and $\mathrm{HSeO}_{2}{ }^{+}$ions, but slightly affected on indium ions. The $\mathrm{CV}$ diagram of solution containing $\mathrm{CuCl}_{2}, \mathrm{InCl}_{3}$ and $\mathrm{SeO}_{2}$ without any complexing (Fig. 4 (a)) agent showed three distinct peaks on the curve, two peaks from $-0.22 \mathrm{~V}$ to $-0.68 \mathrm{~V}$ vs. $\mathrm{Ag} / \mathrm{AgCl}$ were attributed to the reductions of binary compounds, $\mathrm{Cu}_{2-\mathrm{x}} \mathrm{Se}$. The other peak from $-0.68 \mathrm{~V}$ to $-0.92 \mathrm{~V}$ was attributed to the reduction of ternary compound $\mathrm{CuInSe} \mathrm{S}_{2}$. The $\mathrm{CV}$ diagram of mixed solution of its compositional ingredients with TEA exhibited two reduction regions, one is the formation of binary compounds of $\mathrm{Cu}_{2-\mathrm{x}} \mathrm{Se}$ under more negative potential (from $0.34 \mathrm{~V}$ to $0.6 \mathrm{~V}$ ) and the other is the formation of ternary compound $\mathrm{CuInSe}_{2}$ under less negative potential (from $-0.6 \mathrm{~V}$ to $-0.82 \mathrm{~V}$ ). It was clear that the reduction point was delayed due to the influ-

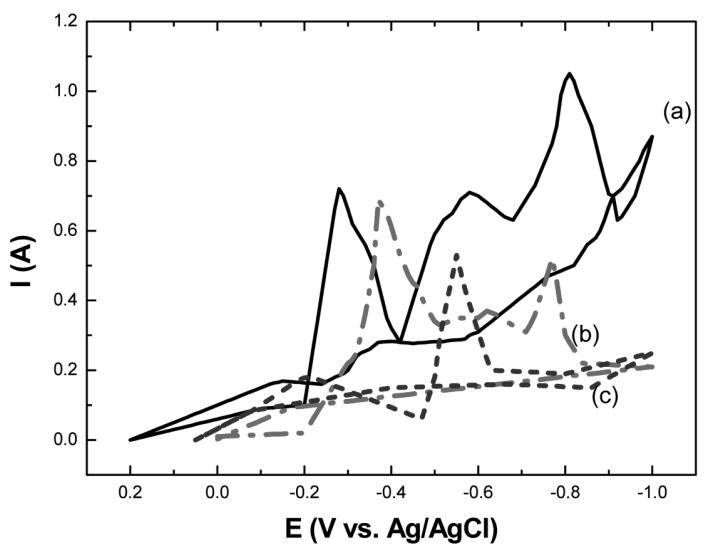

Fig. 4. Cyclic voltammogram of a solution containing $5 \mathrm{mM} \mathrm{CuCl}_{2}, 22 \mathrm{mM} \mathrm{InCl}_{3}, 22 \mathrm{mM} \mathrm{SeO}_{2}$ (a) without complexing agents (solid line) (b) 1.0 M TEA (dash dotted line) (c) $0.4 \mathrm{M}$ sodium citrate (dashed line) [modified from Fig.4 in reference 87 and Fig. 1 of reference 88]. 
ence of TEA. The application of TEA created an environment for co-deposition reaction, but it hindered the reaction to a certain extent at higher concentrations. The $\mathrm{CV}$ diagram of solution containing $\mathrm{CuCl}_{2}, \mathrm{InCl}_{3}$ and $\mathrm{SeO}_{2}$ with citrate ions ${ }^{88)}$ showed two reduction peaks. (Fig. 4 (c)). The reduction peak from $-0.05 \mathrm{~V}$ to $-0.45 \mathrm{~V}$ vs. $\mathrm{Ag} / \mathrm{AgCl}$ was the reduction of binary compound of $\mathrm{Cu}_{2-\mathrm{x}} \mathrm{Se}$, whereas the peak from $-0.45 \mathrm{~V}$ to $-0.65 \mathrm{~V}$ was the reduction of ternary compound of $\mathrm{CuInSe}_{2}$. In this work the optimum potential for deposition of $\mathrm{CuInSe}_{2}$ was found to be $-0.5 \mathrm{~V}$ vs. $\mathrm{Ag} / \mathrm{AgCl}$. The application of sodium citrate created a feasible environment for the co-deposition reaction, not only because it shifted the deposition potentials of copper ions in the negative direction closer to that of indium ions, but also promoted the formation of crystalline films of CuInSe $e_{2}$.

Kemell et al. ${ }^{89)}$ electrochemically prepared In and $\mathrm{Al}$ doped $\mathrm{ZnO}$ thin films on Mo covered glass sheets that were used as transparent conducting top electrode in CIGS solar cell. The cathodic electrodeposition of oxides from nitrate solution was thought to proceed via the reduction of nitrate ions:

$$
\mathrm{NO}_{3}^{-}+\mathrm{H}_{2} \mathrm{O}+2 \mathrm{e}^{-} \rightarrow \mathrm{NO}_{2}^{-}+2 \mathrm{OH}^{-}
$$

The electrochemically generated hydroxide ions then reacted chemically with the metal ions in the solution to form a metal hydroxide deposit at the cathode:

$$
\mathrm{M}^{\mathrm{n}+}+\mathrm{nOH}^{-} \rightarrow \mathrm{M}(\mathrm{OH})_{\mathrm{n}}
$$

Under suitable conditions, during deposition or during post-deposition annealing, the hydroxide decomposed to the corresponding oxide:

$$
\mathrm{M}(\mathrm{OH})_{\mathrm{n}} \rightarrow \mathrm{MO}_{\mathrm{n} / 2}+\frac{\mathrm{n}}{2} \mathrm{H}_{2} \mathrm{O}
$$

Generally, the $\mathrm{Al} /(\mathrm{Zn}+\mathrm{Al})$ or $\mathrm{In} /(\mathrm{Zn}+\mathrm{In})$ ratios in the films decreased towards more negative deposition potentials. More complicated behavior was observed at high $\mathrm{InCl}_{3}$ concentrations: $\mathrm{In} /(\mathrm{Zn}+\mathrm{In})$ ratio first decreased and then increased when the deposition potential became more negative. They suggested that $\mathrm{Zn}_{\mathrm{m}} \mathrm{In}_{2} \mathrm{O}_{3+\mathrm{m}}$ compounds were formed at the negative end of the deposition potential range.

Sun et al. ${ }^{90)}$ studied the electrodeposition of Pd-In on a glassy carbon electrode from a chloride rich 1-ethyl-3methylimidazolium chloride/tetrafluoroborate (EMIC$\mathrm{BF}_{4}$ ) air-stable ionic liquid at $120^{\circ} \mathrm{C}$. Deposition of $\mathrm{Pd}$ alone occurs prior to the overpotential deposition
(OPD) of bulk indium. At low concentration of $\mathrm{In}^{3+}$, the OPD of Pd occurred at a potential far more positive than the OPD of In. As $\operatorname{In}^{3+}$ concentration increased, the underpotential deposition (UPD) of In on the deposited Pd was observed. The UPD of In occurred on Pd at a potential overlapped with the OPD of Pd. Because the UPD of In on Pd was limited by a slow charge transfer rate, the In content in the deposited Pd-In alloys was lower than that in the plating bath.

El Abedin et al. ${ }^{91)}$ studied the electrodeposition of Se, In and $\mathrm{Cu}$ in an air- and water-stable 1-butyl-1-methylpyrrolidinium bis(trifluoromethylsulfonyl)amide $\left([\mathrm{BMP}] \mathrm{Tf}_{2} \mathrm{~N}\right.$ ) ionic liquid. The cyclic voltammograms of the [BMP]Tf $f_{2} \mathrm{~N}$ ionic liqid containing $0.1 \mathrm{M} \mathrm{InCl}_{3}$ on a glassy carbon electrode and polycrystalline platinum electrodes were investigated. The cyclic voltammogram of $\operatorname{In}^{3+}$ on a glassy carbon electrode showed that the reduction of $\mathrm{In}^{3+}$ to indium metal occurred in one step and in the reverse scan, partial stripping of the electrodeposited indium and slower dissolution of larger indium crystallites occurred at $-2.0 \mathrm{~V}$ and $0.0 \mathrm{~V}$ vs. Ptquasi ref., respectively. Unlike in the case of glassy carbon electrode, the cyclic voltammograms recorded on Pt electrodes showed several cathodic processes prior to bulk deposition of indium proceeded, they were presumably correlated with different UPD processes for In on polycrystalline platinum. A new anodic peak appeared at a potential more positive than the potential of the main anodic peak. This peak might result from alloying of In with Pt.

\section{Conclusions}

The standard electrode potentials between indium metal and indium ions were determined in aqueous solutions containing chloride, sulfate, and perchlorate etc. The $\mathrm{In}^{3+}$ ion in an aqueous solution formed the hexaquo complex, $\operatorname{In}\left(\mathrm{H}_{2} \mathrm{O}\right)_{6}{ }^{3+}$, which was hydrolysed to $\operatorname{In}\left(\mathrm{H}_{2} \mathrm{O}\right)_{5}(\mathrm{OH})^{2+}$ and $\operatorname{In}\left(\mathrm{H}_{2} \mathrm{O}\right)_{4}(\mathrm{OH})_{2}{ }^{+}$ions before electron-transfer process or reduced to indium metal by direct discharge. The three-electron charge-transfer process for the electrochemical deposition of $\mathrm{In}^{3+}$ ions and the anodic dissolution of indium metal occured in two consecutive charge-transfer steps and involves an $\mathrm{In}^{+}$ ion as an intermediate. In aqueous solutions containing halide electrolytes, $\mathrm{In}^{+}$and $\mathrm{In}^{3+}$ formed complexes with halide and a disproportionation reaction or a reproportionation reaction of $\mathrm{In}^{+}$was observed. The most favoured electrolyte for the electrodeposition of indium 
was a sulfate solution. The systematic study of electrochemical nucleation and growth during the electrodeposition of indium can be carried out by current transient study. There have been many attempts to prepare the chalcopyrite materials such as $\mathrm{CuInSe}_{2}$ (CIS) and $\mathrm{Cu}(\mathrm{In}, \mathrm{Ga}) \mathrm{Se}_{2}$ (CIGS) by one-step electrodeposition method.

\section{Acknowledgement}

This work was financially supported by National Research Foundation of Korea (2010-0029164).

\section{References}

1. J.R. Mills, R.A. King, C.E.T. White, "Indium", C.A. Hampel (ed) Rare metals handbook, Chapman and Hall Ltd, London, 220-238 (1961).

2. W. Koster and B. Thoma, Z. Metallkd., 46, 291 (1955).

3. D.G. Avery, D.W. Goodwin, W.D. Lawson and T.S. Moss, Proc. Phys. Soc. B, 67, 761 (1954).

4. S. Ozer and C. Besikci J. Phys D: Appl. Phys., 36, 559 (2003).

5. C.S. Johnson, J.T. Vaughey, M.M. Thackeray, T. Sarakonsri, S.A. Hackney, L. Fransson, K. Edström and J.O. Thomas, Electrochem. Commun., 2, 595 (2000).

6. M.I. Khan, X. Wang, K.N. Bozhilov and C.S. Ozkan, J. Nanomater, 2008, 698759 (2008)

7. S.Y. Wang, S.H. Lin and Y.M. Houng, Appl. Phys. Lett., 51, 83 (1987); S. Wang, Fundamentals of semiconductor theory and device physics, Prentice-Hall, Englewood Cliffs, New Jersey, 523 (1989).

8. T.S. Chao, C.L. Lee and T.F. Lei, J. Mater. Sci. Lett., 12, 721 (1993).

9. T. Inushima, V.V. Mamutin, V.A. Vekshin, S.V. Ivanov, T. Sakon, M. Motokawa, S. Ohoya, J. Cryst. Growth, 227-228, 481 (2001).

10. A.G. Bhuiyan, A. Hashimoto and A. Yamamoto, J. Appl. Phys., 94, 2779 (2003).

11. T.P. Pearsall and M. Papuchon, Appl. Phys. Lett., 33, 640 (1978).

12. W.J. Li, Y.N. Zhou and Z.W. Fu, Appl. Surf. Sci., 257, $2881(2011)$.

13. V.A. Williams, J. Electrochem. Soc., 113, 234 (1966).

14. J.L. Vossen and E.S. Poliniak, Thin Solid Films, 13, 281 (1972).

15. A. Yamamoto, M. Tsujino, M. Ohkubo and A. Hashimoto, Sol. Energ. Mat. Sol. C., 35, 53 (1994).

16. H.P.T. Nguyen, Y.L. Chang, I. Shih and Z. Mi, IEEE J. Sel. Top. Quant., 17, 1062 (2011).

17. H. Neff, O.K. Semchinova, A. M.N. Lima, A. Filimonov and G. Holzhueter, Sol. Energy Materials \& Solar Cells, 90, 982 (2006).

18. S.W. Zeng, X.M. Cai and B.P. Zhang, IEEE J. Quantum
Elect., 46, 783 (2010).

19. S. Wagner and P.M. Bridenbaugh, J. Cryst. Growth, 39, 151 (1977).

20. A.N. Tiwari, D.K. Pandya and K.L. Chopra, Sol. Energ. Mater, 15, 121 (1987).

21. M. Kemell, M. Ritala and M. Leskelä, Crit. Rev. Solid State Mater. Sci., 30, 1 (2005).

22. V. S. Saji, S. M. Lee and C. W. Lee, J. Kor. Electrochem. Soc., 14, 61 (2011).

23. C. J. Smithells, W. F. Gale, T. C. Totemeier (eds) Smithells metals reference book, 8th ed. Elsvier Butterworth-Heinemann, Amsterdam (2004).

24. A.M. Alfantazi and R.R. Moskalyk, Minerals Engineering, 16, 687 (2003).

25. R. Piercy and N.A. Hampson, J. Appl. Electrochem., 5, 1 (1975).

26. V.V. Losev and A.I. Molodov, "Indium", A.J. Bard (ed.) Encyclopedia of electrochemistry of the elements, vol. 6. Marcel Dekker Inc, New York, 1-32, (1976).

27. S. Hakomori, J. Am. Chem. Soc., 52, 2372 (1930).

28. A.K. Covington, M.A. Hakeem and W.F.K. WynneJones, J. Chem. Soc., 1963, 4394 (1963).

29. E.M. Hattox and T. De Vries, J. Am. Chem. Soc., 58, 2126 (1936).

30. W. Kangro and F. Weingärtner, Z. Elektrochem., 58, 505 (1954).

31. J. N. Butler, J. Phys. Chem., 68, 1828 (1964).

32. W.J. Hamer, M.S. Malmberg and B. Rubin, $J$. Electrochem. Soc., 103, 8 (1956).

33. L.G. Hepler, Z.Z. Hugus Jr. and W.M. Latimer, J. Am. Chem. Soc., 75, 5652 (1953).

34. R.E. Visco, J. Phys. Chem., 69, 202 (1965).

35. G. Biedermann and T. Wallin, Acta Chem. Scand., 14, 594 (1960).

36. G. Biedermann, Ark. Kem., 9, 277 (1956); G. Biedermann, Rec. Trav. Chim. Pays-Bas., 75, 716 (1956); G. Biedermann and D. Ferri, Acta Chem. Scand. A, 36, 611 (1982).

37. V.V. Losev and A.I. Molodov, Dokl. Akad. Nauk. SSSR, 135, 1432 (1960).

38. A.I. Molodov and V.V. Losev, Elektrokhimiya, 1, 651 (1965).

39. R.J. Clark, E. Griswold and J. Kleinberg, J. Am. Chem. Soc., 80, 4764 (1958).

40. M. Pourbaix, Atlas of Electrochemical Equilibria in Aqueous Solutions, 2nd English ed., Houston, Tex.: Natl Assn of Corrosion, 439 (1974).

41. N.A. Hampson and R. Piercy, J. Electroanal. Chem., 51, 91 (1974).

42. B. Lovrecek and V. Markovac, J. Electrochem. Soc., 109, 727 (1962).

43. V.V. Losev and A.I. Molodov, Proc. Acad. Sci. USSR. Phys. Chem. Sec. (English Transl.), 135, 1203 (1960); V.V. Losev and A.I. Molodov, Electrochim. Acta, 6, 81 (1962).

44. G.M. Budov and V.V. Losev, Proc. Acad. Sci. USSR. 
Phys. Chem. Sec. (English Transl.), 129, 1113 (1959); G. M. Budov and V.V. Losev, Russ. J. Phys. Chem., (English Transl.) 37, 784 (1963).

45. R.E. Visco, J. Electrochem. Soc., 112, 932 (1965).

46. B. Miller and R.E. Visco, J. Electrochem. Soc., 115, 251 (1968).

47. V. Markovac and B. Lovrecek, J. Electrochem. Soc., 112, 520 (1965).

48. V.V. Losev and A.P. Pchelnikov, Electrochim. Acta, 18, 589 (1973).

49. V. Markovac and B. Lovrecek, J. Electrochem. Soc., 113, 838 (1966).

50. J. Heyrovsky, Discuss. Faraday Soc., 1, 212 (1947).

51. J.E.B. Randles, Discuss. Faraday Soc., 1, 11 (1947).

52. R. Parsons and M.A.V. Devanathan, Trans. Faraday Soc., 49, 673 (1953).

53. A.M. Bond, J. Electrochem. Soc., 119, 1503 (1972).

54. P. Kondziela and J. Biernat, J. Electroanal. Chem., 61, 281 (1975).

55. C. Nanjundiah and R. Narayan, Electrochim. Acta, 26, 203 (1981).

56. J. Malyszko and E. Malyszko, Monatsh. Chem., 116, 19 (1985).

57. J. Malyszko and D. Gierulska, Monatsh. Chem., 115, 1401 (1984).

58. D. Gierulska and J. Malyszko, J. Electroanal. Chem., 287, 265 (1990)

59. E. Malyszko and J. Malyszko, Monatsh. Chem., 124, 15 (1993).

60. E. Malyszko and J. Malyszko, Monatsh. Chem., 126, 271 (1995).

61. D. Gierulska and J. Malyszko, Monatsh. Chem., 125, 363 (1994)

62. H.A. Laitinen and C.H. Liu, J. Am. Chem. Soc., 80, 1015 (1958).

63. U. Anders and J.A. Plambeck, Can. J. Chem., 47, 3055 (1969).

64. J. M. Shafir and J.A. Plambeck, Can. J. Chem., 48, $2131(1970)$

65. J.H.R. Clarke and R.E. Hester, Inorg. Chem., 8, 1113 (1969).

66. A. De Guibert and V. Plichon, J. Electroanal. Chem., 90, 399 (1978).

67. M.J. Barbier, J. Bouteillon and M. Taoumi, J. Electrochem. Soc., 133, 2502 (1986).

68. Y. Castrillejo, M.A. Garcia, E. Barrado, P. Pasquier and G. Picard, Electrochim. Acta, 40, 2731 (1995).

69. M. Mohamidi, S. Martinet, J. Bouteillon and J.C.
Poignet, Electrochim. Acta, 44, 797 (1998).

70. M.K. Carpenter and M.W. Verbrugge, J. Mater. Res., 9, 2584 (1994).

71. J.-S. Liu and I.-W. Sun, J. Electrochem. Soc., 144, 140 (1997).

72. J. Bouteillon and M. Jafarian, J. C. Poignet and A. Reidet, J. Electrochem. Soc., 139, 1 (1992).

73. M.-H. Yang and I.-W. Sun, J. Chin. Chem. Soc., 51, 253 (2004).

74. J.R. Mills, B.G. Hunt and G.H. Turner, J. Electrochem. Soc., 100,136 (1953).

75. M.A. Whitehead, Metal Finishing, 4, 405 (1944).

76. R.C. Valderrama, M. Miranda-Hernandez, P.J. Sebastina and A. L. Ocampo, Electrochim. Acta, 53, 3714 (2008).

77. F. Liu, C. Huang, Y. Lai, Z. Zhang, J. Li and Y. Liu, J. Alloy. Compd., 509, L129 (2011).

78. Q. Huang, K. Reuter, S. Amhed, L. Deliglanni, L.T. Romankiw, S. Jaime, P.P. Grand and V. Charrier, J. Electrochem. Soc., 158, D57 (2011).

79. S. Omanovic and M. Metikos-Hokovic, Thin Solid Films, 458, 52 (2004).

80. D. Pottier and G. Maurin, J. Appl. Electrochem., 19, 361 (1989).

81. K.K. Mishra and K. Rajeshwar, J. Electroanal. Chem., 271, 279 (1989).

82. L. Thouin, S. Massaccesi, S. Sanchez and J. Vedel, J. Electroanal. Chem., 374, 81 (1994).

83. L. Thouin and J. Vedel, J. Electrochem. Soc., 142, 2996 (1995).

84. M.C.F. Oliveira, M. Azevedo and A. Cunha, Thin Solid Films, 405, 129 (2002).

85. T. Ishizaki, N. Saito and A. Fuwa, Surf. Coat. Tech., 182, 156 (2004).

86. M. Pourbaix, Atlas of Electrochemical Equilibria in Aqueous Solutions, 2nd English ed., Houston, Tex.: Natl Assn of Corrosion, 387 (1974).

87. T.J. Whang, M.T. Hsieh, Y.C. Kao and S.J. Lee, Appl. Surf. Sci., 255, 4600 (2009).

88. T.J. Whang, M.T. Hsieh and Y.C. Kao, Appl. Surf. Sci., 257, 1457 (2010).

89. M. Kemell, F. Dartiques, M. Ritala and M. Leskelä, Thin Solid Films, 434, 20 (2003).

90. S.-I. Hsiu, C.-C. Tai and I.-W. Sun, Electrochim. Acta, 51, 2607 (2006).

91. S.Z. El Abedin, A.Y. Saad, H.K. Farag, N. Borisenko, Q.X. Liu and F. Endres, Electrochim. Acta, 52, 2746 (2007). 